\title{
Restorative Justice For The Settlement Of Criminal Acts Of Employment In Toursim Sector
}

\author{
I Made Dwi Dinaya \\ \{info@warmadewa.ac.id\} \\ Master Program In Law Universitas Warmadewa, Denpasar, Bali
}

\begin{abstract}
This study is motivated by the handling of criminal cases with a restorative justice approach that offers different approach and standpoint in comprehending and handling criminal acts. Labor law in the tourism sector with the form of restorative justice is increasingly developing in criminal law, especially those relating to the handling of criminal acts in employment in the tourism sector. The aims of this research are to identify the characteristics of restorative justice and the law enforcement system in Indonesia and to describe the application of restorative justice in handling criminal acts in the tourism sector. The theories used are restorative justice theory, justice theory, and legal certainty theory. This study is designed by employing normative law research method, which are supported by legislative approach and conceptual approach. The core discussion is divided into two. The first is to describe the characteristics of restorative justice in the law enforcement system in Indonesia and, second, to present the information about the system applying restorative justice application in handling the criminal acts in the tourism sector. The conclusion is the restorative justice in the law enforcement system in Indonesia has the character that upholds the harmonization of relations between the perpetrators and victims, between the perpetrators, the families of the victims, and the families of the perpetrators. The justice of restorative justice in the criminal acts in the tourism sector is applied by providing a sense of peace in the process of legal settlement, and guaranteeing the restoration of assets (losses) experienced by victims of criminal acts in the tourism sector.
\end{abstract}

Keywords: Restorative Justice, Justice and Legal Certainty.

\section{Introduction}

The 1945 Constitution guarantees the right of every citizen to obtain a job, namely in article 27 paragraph 2. This is reaffirmed in the Article 28 D of Chapter XA of the 1945 Constitution of the Republic of Indonesia (the result of the second amendment) on Human Rights (article 28A-28J) mandated that "every person is entitled to work and to receive compensation and fair and proper treatment in work relations. The development of tourism in Indonesia is growing rapidly, especially in Bali. Tourism policy in the Broad Outlines of State Policy of 1999-2018 strongly underpins the tourism in Bali, which is inseparable from the field of hospitality accommodation, especially with the many international standard hotels, 
budget hotels, restaurants and entertainment venues as well as travel agencies that support the employment sector; everything is inseparable from the law of the scope of labor law implementation. This regulation does not only govern the relationship between workers or laborers and employers in the implementation of work relations but also includes a person who is looking for work through the right process, or the related implementing institutions and concerning the workers or laborers who are retired.

Labor law is a written regulation that governs a person starting from before, during, and after becoming a laborer related to the scope of employment. If this rule is violated, it can be given civil or criminal sanctions, including to organizers related to the field of labor.

Law enforcement is strongly influenced by environmental conditions. Environment has great potential in triggering criminal acts in employment in the tourism sector, for example the one that is clearly seen in the management of tourism in Indonesia, especially in Bali. The implementation of tourism upholds cultural values, and this principle is stated in article 5 of Law Number 10 of 2009 concerning tourism (Law No. 10/2009). In more detail, the implementation of tourism upholds the value stated in article 5 letter a, which stipulates that the tourism shall uphold religious norms and cultural values as an embodiment derived from the concept of life in the balance of the relationship between human and God Almighty, between humans and their fellowship, and between human and environment.

Tourism, in a narrow sense, refers to travel activities for the sake of personal refreshment, for education, and for pleasures. Meanwhile, in a broadest sense, tourism is a business (enterprise) that provides information, transformation, accommodation and other services for tourists. As in Article 3 of Law No. 10/2009, stated that tourism serves to meet the physical, spiritual, intellectual needs of every tourist with recreation and travel, as well as increasing the state revenues to realize people's welfare.

The handling of criminal cases with a restorative justice approach offers a different view and approach in understanding and resolving the criminal acts. In the view of restorative justice, the meaning of criminal acts is basically the same as the view of criminal law in general, namely attacks on individuals and communities and community relations. However, in a restorative justice approach, the main victims of a criminal act are not the state, as in the current criminal justice system. Because of this, crime creates an obligation to fix the damage to relationships caused by criminal acts. Meanwhile, justice is interpreted as a process of finding solutions to problems in the form of criminal cases that occur, in which the involvement of victims, communities and actors is important in an effort to realize restoration, reconciliation and guaranteeing the continuity of the improvement of the business.

Certainly, this research is inseparable from many studies that have been conducted previously, [1] conducted study about restorative justice in settlement of minor offences. On the study it revealed that common criminal offences may be settled by penal mediation which is usually called the restorative justice approach, that focuses on immediate participation of perpetrators, victims and the public in understanding the offences. Another latest related study was about restorative justice as an alternative in resolving criminal acts and their influence in the criminal justice system in Indonesia. Restorative justice returns conflict to the most affected parties such as victims, perpetrators, and the community, and prioritizes their interests. With law enforcement through restorative justice it is expected that the losses and suffering suffered by victims and their families can be restored and the burden of guilt of criminals can be reduced because they have received forgiveness from victims or their families [2]. [3] on juridical review of the principle of restorative justice in cases of embezzlement of research stated that the application of restorative justice in embezzlement crimes cases gives freedom to the public in solving problems in the community in this 
settlement of embezzlement crime cases. Based on these latest related research reviews above, it is needed to carry out a research on settlement of criminal acts of employment in tourism sector that has been never studied with the aims of research are to identify the characteristics of restorative justice and the law enforcement system in Indonesia and to describe the application of restorative justice in handling criminal acts in the tourism sector.

\section{Method}

This type of research is normative or doctrinal legal research [4], which are supported by legislative approach and conceptual approach. The approach to the problem used in this study is the approach: statute approach, conceptual approach, and case approach [5]. The core discussion is divided into two. The first is to describe the characteristics of restorative justice in the law enforcement system in Indonesia and, second, to present the information about the system applying restorative justice application in handling the criminal acts in the tourism sector. The theories used are Restorative Justice Theory, Justice Theory, and Legal Certainty Theory.

\section{Result And Discussion}

\subsection{Restorative Justice in the Law Enforcement System}

Law enforcement in tourism crime must be interpreted in a broad sense, because in addition to the enforcement, it must also include measures to prevent criminal acts and restore the condition of the company (reputation) to maintain public trust in the tourism sector in particular and the law enforcement system in general. This is important considering the development and stability of tourism is very much influenced by the security system, including tourism which is a source of foreign exchange for the country's very large income to date. According to Sudarto, the law enforcement is the concern and cultivation of acts that are unlawful which actually have occurred (onrecht in actoe) or possible illegal acts (onrecht in potentie) [6]. Joseph Goldstein provides three concepts related to the law enforcement, namely:

1. Total enforcement, that is, enforcement of criminal law as expected and formulated by material criminal law (substantive law of crime).

2. Full enforcement, that is, law enforcers are expected to enforce the law optimally even though with various obstacles in its implementation in the form of time constraints, personnel, investigative tools, and so on, it is necessary to have discretion.

3. Actual enforcement, that is, real law enforcement as a result of total enforcement minus area of no enforcement results in full enforcement, and after a reduction in discretion, it results in an actual law enforcement.

Prof. Sudarto stated that the Criminal Law is a statutory regulation that is only intended to impose criminal sanctions on rules concerning one of the fields that are located outside the criminal law or not the Criminal Law in the "real meaning". It is a law which, according to its purpose, is intended to regulate criminal rights of the state, guarantees, and public order. Therefore it is appropriate to consider the use of non-penal facilities (non-criminal sanctions). 
It is highly recommended that it is not a criminal law that should be applied in determining the recovery or reversioan of losses as a result of a criminal offense. Instead, restorative justice is recommended. It is an effort, an approach or a new dispute resolution model in Indonesia that is very close to the principle of deliberation which is the soul of the nation (volkgeist) of Indonesia itself. Restorative justice provides the best solution in settling the cases of private crimes between people (natuurlijkpersonen) or legal entities (rechtpersonen), namely by giving priority to the core problems of a crime. The important thing to note in resolving a criminal case is the restoration of the social order of the community for those who are stricken or victims of a crime. Restorative justice focuses on the criminal accountability process directly from the perpetrator to the victim and the community; if the perpetrators and victims as well as the community whose rights are violated, feel that a justice through a joint deliberation effort has been reached, punishment can be shun.

From the results of the study, conclusions can be drawn, that is to say, the implementation of restorative justice in the settlement of criminal cases of embezzlement gives freedom to the community in directing problems in the community to peace, in this case the settlement of criminal cases of embezzlement. Apart from that, reason mediation can be applied in the process of resolving embezzlement cases, outside conventional courts, as a material from restorative justice. In turn, it discusses the scope of the relationship between amnesties. Relation between amnesty and reconciliation more specifically places the amnesty as an important part of reconciliation. In this chapter we will develop the discussion by placing both in the context of the restorative justice agenda.

Other restorative justice practices that are similar to Victim-offender mediation, especially seen from the process of their appearance are sentencing circles. The sentencing circles, or also known as Community Circles or Healing Circles, are also born from experimental efforts in the context of criminal justice institutions in order to look for models of decisions that are community-based and are rehabilitative or restorative. What will be a serious challenge for defenders of justice is facing the fact that individuals in modern society are increasingly showing a tendency to isolate one another, and often they do not imagine that they are bound in relationships or feel being a part of certain community or society, even in the micro sense, as Braithwaite's view above. In this context, we must be realistic, in that, the directed support from the government or established institutions will greatly determine the success or failure of the practice of restorative justice for modern society, because it would be naive if we expect them to be able to carry it out independently and voluntarily. Supports from official institutions in the following years have in fact played a decisive role in the success of restorative practices, especially if they were initially accepted as a direct response or alternative mechanism for the dominance of the criminal justice system.

A Restorative Justice serves as one the sources of consideration for public policies. In the late decade of the $1980 \mathrm{~s}$, a number of countries and organizations began to explore the policy implications of what they had learned from restorative processes. Through a program called Justice Fellowship, the United States begins their long-term project to translate restorative vision into public policy principles. In the same period, the Canadian parliament has also ratified a number of fundamental changes in terms of penalization mechanisms after they have witnessed an increase in the success of restorative processes.

After outlining the spirit carried along with the parameter values contained in restorative justice, there is a subsequent important issue that must be addressed immediately, namely the issue of what definitions we should make to summarize the various opinions that arise, so that we then have a more solid depiction of what we mean by restorative justice. Before the definition is stated, we need to identify the basic concepts of what supports it, and to facilitate 
this step we will refer to the explanation made by Gerry Johnstone and Daniel Van Ness. From the results of an in-depth review, both of them presented variative opinions about restorative justice. John Rawls argued that the concept of justice is fairness, which contains principles that free and rational people who want to develop their interests, should obtain a similar position when they will start and that is a fundamental requirement for them to enter the meetings they prefer [6]. John Rawls writes that fairness consists of two points; (1) interpretation of the initial study and on the problems of choice, and (2) a set of principles that will be agreed upon [7]. Furthermore, regarding the theory of legal certainty, according to Sudikno Mertokusumo the main purpose of the law is to create order and balance [8]. On the other hand, some law circles argue that the law is aimed to achieve justice (ethical theory), usefulness (utilization theory), and objecifying orderliness (mixed theory).

\subsection{The Implementation of Restorative Justice in Criminal Settlement in the Tourism Sector}

Criminal acts committed by workers in the field of tourism, which cause companies or employers to terminate employment, previously regulated in Law Number 13 of 2003 concerning employment (Labor Law), namely in Article 158 paragraph (1) letter J concerning Labor Law, which states that employers can terminate employment with workers on the grounds that the workers have perpetrated serious mistakes, such as: a) committing fraud, theft, or embezzlement of goods and / or money belonging to the company. For example, there are employees who carry out criminal violations, either against the company or against other employees, but are not criminally processed for one or more factors, then, does that mean that the employee cannot be dismissed because he or she is not proceeding to the criminal court process?

The foregoing does not prescribe whether a worker shall receive a salary if he/she commit a crime. However, workers still have some rights as stipulated in article 160 paragraph (1) of the Labor Law which stipulates that: in the event that workers are detained by the authorities because they are suspected of committing a criminal offense not on a complaint of the employer, employers are not obliged to pay wages but are shall provide assistance to the families of the workers who are dependent on them on the following conditions:

a. For 1 dependent person: $25 \%$ (twenty five percent) of wages;

b. For 2 dependents: $35 \%$ (thirty five percent) of wages;

c. For 3 dependents: $45 \%$ (forty five percent) of wages;

d. For 4 dependents: 50\% (fifty percent) of wages.

In the second principle of the Pancasila, the five basis of Indonesian state, which reads, "Both just and civilized Humanity" implies that every Indonesian citizen gets protection and fair treatment in the eyes of the law, including workers in the tourism sector. In other words, even if they commit a crime, they still have to account for the extent of their mistakes before the law. In the fifth principle of Pancasila, which reads, "Social Justice for all the people of Indonesia", it is indicated that every Indonesian people must obtain justice in accordance with their responsibilities, which means not to abolish their crimes.

The examples of cases of criminal acts of workers in the sector of tourism:

1. The theft of goods in the form of VCD Player at Hard Rock Hotel by workers named Agus and arrested by the security, as reported by the police manager, but the price of the goods is under two million. The process was not continued but revoked by the worker manager because the perpetrator was imposed a sanction in the form of termination of employment and the perpetrator obtained his rights in accordance with Law Number 13 of 2003 Article 156. 
2. Theft of goods in the form of Hotel Guest Leather Jacket committed by an employee named Made Sudeni at Club Med Nusa Dua Bali which was recorded by CCTV. The perpetrator was arrested by the security forces and not reported by the manager to the police but settled peacefully; the process was not continued by the employer because the employee was given a termination of employment and the she obtained her rights in accordance with Law Number 13 of 2003 Article 156.

Through the two illustrations above, the implementation of the restorative justice theory is shown. The efforts to resolve criminal cases with the restorative justice approach are actually a process that focuses more on conditions to create justice and / or balance for the community. Restorative justice is an approach to making transfer and institutionalization in accordance with justice. In the formulation of the second and the five precepts of Pancasila, there is the word "justice" which demands that indeed justice must be enforced and upheld. The enforcement of justice in community life has an important sense in one of the efforts to build a nation's civilization if it is not based on fairy life. This is where the law functions as a protector for human interests and creates order and balance so that justice expected is achieved. The application of Restorative Justice in the settlement of criminal acts of workers in the sector of tourism is normatively supported by the 1945 Constitution which guarantees the right of every citizen to obtain the work (article 27 paragraph 2). This is reaffirmed in Chapter XA of the 1945 Constitution of the Republic of Indonesia (as a result of the second amendment) on Human Rights (article 28A-28J). Article 28 D mandates that "every person shall be entitled to work and receive compensation and fair and proper treatment in the work relations. Furthermore, in article 28 I paragraph (4) it is affirmed that the protection, promotion, enforcement, and fulfillment of human rights are the responsibility of the state, especially the government.The concept of the rule of law lies in the welfare of society. However, this is adjusted to the type of state of welfare law adopted in developed countries. The Indonesian welfare state is in accordance with the personality of the Indonesian people based on Pancasila. The Indonesian state of law is more inclined to the type of legal state whose people actively participate in development, not a welfare state whose people are passive, even though their governments are preparing all kinds of social welfare services.

Bulding upon the description above, the theory used to analyze this discussion is the Restorative Justice theory according to [9], who argues that restorative justice is a concept of thought that responds to the development of the criminal justice system by focusing on the need to involve the public and victims who are perceived to be marginalized by the mechanism that works in the current criminal justice system, in contrast to systems that previously existed. This approach focuses on the direct participation of perpetrators, victims, and communities in the process of settling the criminal cases [9].

\section{Conclusion}

Based on the results of the study, there are several conclusions that can be drawn, they are the characteristics of justice restorative justice in the law enforcement system in Indonesia have a character that upholds the harmonization of relations between the perpetrators and the victims, between the perpetrators and the family of victims, and between the family of perpetrators and the family of the victim. Therefore, these characteristics can overcome the losses incurred as a result of criminal acts in business in the tourism sector. The application of justice for restorative justice in the settlement of criminal acts in tourism sector is conducted 
by giving a sense of peace in the process of legal settlement and also by guaranteeing the recovery of assets (losses) experienced by victims, so that when associated with tourism business activities that prioritize the principle of prudence and efficiency, this approach can be used to accelerate the process of resolving legal issues, especially those related to criminal acts in the tourism sector.

\section{References}

[1] Muhaimin, "Restoratif Justice dalam Penyelesaian Tindak Pidana Ringan," J. Penelit. Huk. Jure, vol. 19, no. 2, 2019.

[2] H. S. Flora, "Keadilan Restoratif Sebagai Alternatif dalam Penyelesaian Tindak Pidana dan Pengaruhnya dalam Sistem Peradilan Pidana di Indonesia," Ubelaj, vol. 3, no. 2, 2018.

[3] J. D. Wagiu, "Tinjauan Yuridis Terhadap Asas Keadilan Restoratif dalam Perkara Tindak Pidana Penggelapan," Lex Crim., vol. 4, no. 1, 2015.

[4] S. Soekanto and S. Mamudji, Penelitian Hukum Normatif: Suatu Tinjauan Singkat. Jakarta: PT. Raja Grafindo Persada, 2001.

[5] P. M. Marzuki, Penelitian Hukum. Jakarta: Kencana Prenada Media Group, 2009.

[6] Sudarto, Hukum dan Hukum Pidana. Bandung: Penerbit Alumbi, 1986.

[7] J. Rawls, A Theory of Justice. Jakarta: Pustaka Pelajar, 1995.

[8] S. Metokusumo, Mengenai Hukum: Suatu Pengantar, 2nd ed. Yogyakarta: Liberty, 1999.

[9] E. A. Zulfa, "Keadilan Restoratif di Indonesia: Studi tentang kemungkinan Penerapan Pendekatan Keadilan Restoratif dalam Praktek," Univ. Indones., 2009. 